\title{
PENGARUH KUALITAS PELAYANAN KESEHATAN TERHADAP KEPUASAN PASIEN PUSKESMAS KECAMATAN PANCA RIJANG KABUPATEN SIDENRENG RAPPANG
}

\author{
${ }^{1)}$ Nurlina Anggraeni, ${ }^{2}$ Sapri, ${ }^{3)}$ Rifni Nikmat Syarifuddin \\ Fakultas IImu Sosial dan IImu Politik Universitas Muhammadiyah Sidenreng Rappang \\ nurlina.anggrainii43152039a1@gmail.com \\ sapritajuddin272@yahoo.co.id
}

\begin{abstract}
Abstrak
Penelitian ini bertujuan untuk mengetahui Kualitas Pelayanan Kesehatan Puskesmas Kecamatan Panca Rijang Kabupaten Sidenreng Rappang dan Kepuasan Pasien Puskesmas Kecamatan Panca Rijang Kabupaten Sidenreng Rappang dan Pengaruh Kualitas Pelayanan Kesehatan terhadap Kepuasan Pasien Puskesmas Kecamatan Panca Rijang Kabupaten Sidenreng Rappang. Populasi dalam penelitian ini adalah keseluruhan pasien rujukan rawat jalan dan kunjungan rawat jalan di Puskesmas Kecamatan Panca Rijang yaitu 2,114 orang. Sampel yang di gunakan peneliti adalah 95,48 dibulatkan 95 responden, diambil berdasarkan teknik insidental sampling. Tipe penelitian ini adalah Deskriptif Kuantitatif. Teknik pengumpulan data yang digunakaan dalam penelitian ini adalah observasi, koesioner, wawancara dan studi kepustakaan. Data yang yang terkumpul kemudian digunakan dengan cara teknik analisis data, dengan menggunakan SPSS 16.0 for Windows dan Skala Likert. Hasil penelitian ini menunjukkan bahwa kualitas pelayanan kesehatan Puskesmas Kecamatan Panca Rijang Kabupaten Sidenreng Rappang dengan rekapitulasi 58,12\% dikategorikan kurang baik. kepuasan pasien Puskesmas Kecamatan Panca Rijang Kabupaten Sidenreng Rappang dengan rekapitulasi $63,2 \%$ dikategorikan baik, meski demikian, diketahui bahwa terdapat masalah pada indikator lokasi $60,4 \%$, fasilitas $57 \%$, imange $60 \%$. Pengaruh kualitas pelayanan kesehatan terhadap kepuasan pasien Puskesmas Kecamatan Panca Rijang Kabupaten Sidenreng Rappang dengan nilai thitung $\geq$ ttabel1.740 $\geq 1.661$ maka Ho ditolak dan Ha diterima, artinya berpengaruh/signifikan.
\end{abstract}

Kata kunci: Kualitas Pelayanan dan Kepuasan Pasien

\begin{abstract}
This study aims to determine the Health Service Quality of Panca Rijang Health Center, Sidenreng Rappang and to out the Patient Statisfaction of Panca Rijang Health Center in Sidenreng Rappang and the Effect of Quality of Health Service on Patient Satisfaction in Panca Rijang Health Center, Sidenreng Rappang. The population of this study was all outpatient referral patients and outpatient visit at the Panca Rijang District Public Health Center, namely 2114 people. The sample used by researchers was 95.48 or 95 respondents, taken based on insedental sampling techniques. This type of research is descriptive qualitative. Data collection techniques used in this study are observation, questionnaire, interview and library study. The collected data is then used by means of data analysis techniques, using SPSS 16.0 for Windows and the Likert Scale. The results of this study indicate that the quality of health service at the subdistrict health center in the five district of Panca Rijang district Sidenreng Rappang with a recapitulation of $58,12 \%$ categorized as not good. Satisfaction of patiens in the district health center Panca Rijang regency Sidenreng Rappang with a recapitulation of $63,2 \%$ categorized as good, however, it is know that there is a problem with the location indicator $60,4 \%$ facility $57 \%$, image $60 \%$. Effect of Quality of Health Service on Patienst Satisfaction in Panca Rijang District Health Center, Sidenreng Rappang Districtwith a value of $t_{\text {hitung }} \geq t_{\text {tabel }} 1.740 \geq 1.661$, then $\mathrm{Ho}$ is rejected and Ha is accepted, meaning that it is significant.
\end{abstract}

Keywords: Service Quality and Satifaction 


\section{A. PENDAHULUAN}

Undang-Undang Nomor 25 Tahun 2009 Tentang Pelayanan publik Pasal 1 ayat (1) pelayanan publik adalah kegiatan atau rangkaian kegiatan dalam rangka pemenuhan kebutuhan pelayanan sesuai dengan peraturan perundang-undang bagi setiap warga negara dan penduduk atas barang, jasa, dan atau pelayanan administratif yang disediakan oleh penyelenggara pelayanan publik.

Keputusan Mentri Pendayagunaan Aparatur Negara (KEPMENPAN) No. 38 Tahun 2012 Tentang Pedoman Penilaian Kinerja Unit Pelayanan Publik. Pelayanan publik merupakan suatu kegiatan untuk dalam rangka memenuhi kebutuhan pelayanan publik dan sesuai dengan aturan undang-undang bagi setiap warga negara dan penduduk atas barang, jasa, atau pelayanan administrasi disediakan senua penyelenggara pelayanan. Peraturan Menteri Kesehatan Republik Indonesia Nomor 43 Tahun 2016 tentang SPM dan Mentri Kesehatan Republik Indonesia menimbang: a) Bahwa berdasarkan Undang-Undang Nomor 23 Tahun 2014 tentang Pemerintahan Daerah, urusan kesehatan merupakan urusan pemerintahan yang dibagi antara Pemerintah Pusat, Pemerintah Daerah provinsi dan Pemerintah Daerah kabupaten/kota, bersifat wajib, dan terkait dengan pelayanan dasar; b) bahwa untuk menjamin tercapainya sasaran dan prioritas pembangunan nasionel bidang kesehatan, diperlukan pedoman Standar Pelayanan Minimal (SPM) yang ditetapkan oleh Pemerintah Pusat; c) bahwa berdasarkan pertimbangan sebagaimana dimaksud dalam huruf a dan huruf $b$, perlu menetapkan Standar Pelayanan Minimal Bidang Kesehatan. Menetapkan : Peraturan Menteri Kesehatan Tentang Standar Pelayanan Minimal Bidang Kesehatan Pasal 1 'berbunyi' Standar Pelayanan Minimal Bidang Kesehatan, yang selanjutnya disingkat SPM Bidang Kesehatan merupakan acuan bagi Pemerintah Daerah Kabupaten/Kota dalam penyediaan pelayanan kesehatan yang berhak diperoleh setiap warga secara minimal. Pasal 2 (1) Pemerintah Daerah Kabupaten/Kota menyelenggarakan pelayanan dasar kesehatan sesuai SPM Bidang Kesehatan. (2) SPM Bidang Kesehatan sebagaimana dimaksud pada ayat
a) Setiap ibu hamil

mendapatkan pelayanan antenatal sesuai standar; b) Setiap ibu bersalin mendapatkan pelayanan persalinan sesuai standar; c) Setiap bayi baru lahir mendapatkan pelayanan kesehatan sesuai standar; d) Setiap balita mendapatkan pelayanan kesehatan sesuai standar; e) Setiap anak pada usia pendidikan dasar mendapatkan skrining kesehatan sesuai standar; f) Setiap warga negara indonesia usia 15 s.d. 59 tahun mendapatkan skrining kesehatan sesuai standar; g) Setiap warga negara usia 60 tahun ke atas mendapatkan skrining kesehatan sesuai standar; h) Setiap penderita hipertensi mendapatkan pelayanan kesehatan sesuai standar; i) Setiap penderita Diabetes Melitus mendapatkan pelayanan kesehatan sesuai standar; j) Setiap orang dengan gangguan jiwa (ODGJ) mendapatkan pelayanan kesehatan sesuai standar; k) Setiap orang dengan TB mendapatkan pelayanan TB sesuai standar; dan I) Setiap orang berisiko terinfeksi HIV (ibu hamil, pasien TB, pasien IMS, waria/transgender, pengguna napza, dan warga binaan lembaga permasyarakatan)

pemeriksaan HIV sesuai standar.

$$
\text { Peraturan Pemerintah Republik }
$$

Indonesia Nomor 47 Tahun 2016 tentang Fasilitas Pelayanan Kesehatan Pasal 1 ayat 1 berbunyi "fasilitas pelayanan kesehatan adalah suatu alat dan/atau tempat yang digunakan untuk menyelenggarakan upaya pelayanan kesehatan, baik promotif, preventif, kuratif maupun rehabilitatif yang dilakukan oleh pemerintah, pemerintah daerah, dan atau masyarakat. Menurut undang-undang No.44 Tahun 2009 tentang hak dan kewajiban pasien adalah memperoleh informasi mengenai tata tertib dan peraturan yang berlaku di rumah sakit, memperoleh informasi tentang hak dan kewajiban pasien, memperoleh layanan yang manusiawi, adil jujur, dan tanpa diskriminasi, memperoleh layanan kesehatan yang bermutu sesuai dengan standar propesi dan standar prosedur operasional, memperoleh layanan yang efektif dan efisien sehingga pasien terhindar dari kerugian fisik dan materi, mengajukan pengaduan atas kualitas pelayanan yang didapatkan, memilih dokter dan kelas perawatan sesuai dengan keinginan dan peraturanyang berlaku di rumah sakit, meminta konsultasi tentang penyakit yang dideritanya kepada dokter lain yang mempunyai Surat Izin Praktik (SIP) baik 
dalam maupun luar rumah sakit, mendapat privasi dan kerahasiaan penyakit yang di derita termasuk data-data medisnya.

Upaya mewujudkan kepuasan pasien memang tidak mudah, oleh karena itu pihak manajemen puskesmas harus dapat melihat apa yang diinginkan oleh pasien dan sebagai penyedia jasa, puskesmas harus mampu memberikan perhatian pada kualitas pelayanan yang unggul. Pada umumnya pasien mengharapkan jasa yang mereka dapatkan dapat diterima dan dinikmati dengan pelayanan yang baik atau memuaskan. Oleh karena itu puskesmas tentunya berupaya untuk memberikan jasa atau pelayanan yang baik kepada pasiennya. Salah satu bentuk upaya pemerintah dalam menyelenggarakan kesehatan kepada masyarakat maka di tiap kecamatan dibangun instansi pemerintah sebagai unit penyelenggara pelayanan kesehatan masyarakat, yakni Pusat Kesehatan Masyarakat atau yang biasa disebut Puskesmas, Untuk mencapai derajat kesehatan masyarakat yang setinggitingginya melalui upaya kesehatan seperti yang direncanakan dalam Peraturan Menteri Kesehatan Republik Indonesia nomor 75 tahun 2014 tentang Pusat Kesahatan Masyarakat (Puskesmas) perlu adanya pelayanan kesehatan yang baik dan berkualitas oleh penyelenggara kesehatan, oleh sebab itu dituntut kinerja yang tinggi dari penyelenggara kesehatan itu sendiri.

Pasien menilai kualitas umumnya setelah pasien tersebut menerima jasa atau pelayanan dari instansi tertentu. Pasien akan menilai kualitas pelayanan melalui 5 aspek penting sebagai tolak ukurnya yaitu tangibles realibility, responsiveness, assurance dan empathy. Kelima aspek ini dikenal dengan dimensi kualitas jasa. Penilaian kualitas pelayanan pada pihak pemberi layanan dapat dijadikan sarana yang tepat bagi instansiinstansi jasa untuk mengetahui hal-hal apa saja yang perlu dibenahi. Pada akhirnya semua kegiatan pelayanan yang diberikan kepada pasien bertujuan memberikan kepuasan bagi pasien. Hasil observasi yang dilakukan oleh peneliti pada awal bulan oktober 2018 di Puskesmas Kecamatan Panca Rijang, dari Bukti fisik (Tangibles), yaitu ruang tunggu yang digunakan pasien untuk menunggu antrian kurang memadai sehingga beberapa orang dari pasien ada yang berdiri dan menunggu diluar. Keandalan
(Realibility), yaitu masih terdapat pasien yang mengeluh dikarenakan proses antrian yang cukup panjang terutama pasien yang menggunakan BPJS dimana mereka terlebih dahulu harus mendaftar di bagian administrasi dan setelah itu menunggu nomor antrian disebutkan. Daya Tanggap (Responsiveness), yaitu petugas dalam memberikan pelayanan masih kurang cepat dan tanggap sehingga hal tersebut berdampak pada kualitas pelayanan kesehatan yang kurang optimal. Jaminan (Assurance) tidak bisa dipungkiri bahwa di setiap instansi pasti ada petugas yang kurang ramah kerena memang itu sudah menjadi karakter dari pribadi individu, dan di puskesmas ini masih terdapat petugas yang kurang ramah terhadap pasien yang berkunjung atau pasien yang datang hanya sekedar mengurus keperluan seperti mengurus surat keterangan sehat, Empati (Empathy) seperti yang kita ketahui di suatu instansi atau tempat pelayanan pasti selalu ditemukan pemberi layananan bersikap diskriminasi atau membeda-bedakan terhadap yang dilayani tidak bisa dipungkiri dengan melihat hubungan keakraban teman, keluarga serta memandang status sosial tinggi petugas yang memandang hubungan keakraban dengan pasien tersebut mudah mendapatkan pelayanan dengan baik sedangkan yang kurang akrab harus menunggu terlebih dahulu dan hal seperti ini masih ditemukan meski demikian instasi yang terkait tersebut walaupun sisi pelayanannya sudah baik dan sudah diakui kualitasnya tetapi dengan sikap perseorangan yang memberi layanan yang berada diwilayah kerjanya masih tidak melakukan tugas dan fungsinya yang seharunya menjadi amanah baginya.

Pasien baru akan merasa puas jikalau kinerja pelayan kesehatan akan diperoleh dan fasilitas yang ditawarkan sesuai dengan harapan masyarakat. Maka hal ini dapat disimpulkan bahwa kepuasan pasien merupakan suatu tingkat perasaan pasien yang timbul dikarenakan hasil dari membandingkan kinerja layanan kesehatan yang diterimanya dengan apa yang diharapkannya (Sabarguna, 2009).Namun dipuskesmas Kecamatan Panca Rijang beberapa masyarakat masih menganggap kondisi lingkungan puskesmas kurang baik hal tersebut mungkin dikarenakan cara penataan, kerapian dan kebersihan 
lingkungannya. Fasilitas pelayanan di puskesmas seperti tempat parkir masih kurang memadai sehingga hal ini dapat menghambat kelancaran kegiatan pelayanan seperti ketika parkir kendaraan sembarang tempat akan menutupi jalan. Hal tersebut kemungkinan menjadi pengalaman yang kurang baik bagi pasien yang berobat di Puskesmas Kecamatan Panca Rijang padahal disisi lain, masyarakat merindukan pelayanan kesehatan yang baik cepat dengan adanya keseimbangan antara kekuasaan yang dimiliki dengan tanggung jawab yang mesti diberikan kepada mayarakat yang dilayani.

Melihat fenomena di atas penulis tertarik untuk mengangkat permasalahan ini ke dalam penelitian ilmiah. Adapun judul yang diangkat:"Pengaruh Kualitas Pelayanan Kesehatan Terhadap Kepuasan Pasien Puskesmas Kecamatan Panca Rijang Kabupaten Sidenreng Rappang"dengan tujuan Untuk mengetahui kualitas pelayanan kesehatan Puskesmas Kecamatan Panca Rijang Kabupaten Sidenreng Rappang, Untuk mengetahui kepuasan pasien Puskesmas Kecamatan Panca Rijang Kabupaten Sidenreng Rappang, dan Untuk mengetahui pengaruh kualitas pelayanan kesehatan terhadap kepuasan pasien Puskesmas Kecamatan Panca Rijang Kabupaten Sidenreng Rappang. Gronros, Nursya'bani Purnama (Akbar, 2017) menyatakan kualitas layanan meliputi:

1. Kualitas Fungsi, merupakan bagaimana layanan yang akan dilaksanakan diantaranya, indikator kontak konsumen, sikap serta perilaku, hubungan internal, penampilan, kemudahan akses, dan service mindedness.

2. Kualitas teknis dengan keluaran yang dirasakan oleh konsumen diantaranya, harga, ketetapan waktu, kecepatan memberikan layanan, dan estetika output.

3. Reputasi perusahaan, yang dicerminkan oleh citra perusahaan dan reputasi di mata konsumen.

Pendapat tersebut dapat disimpulkan bahwa kualitas pelayanan dapat diartikan sebagai standar suatu proses harus dilaksanakan dalam unsur suatu kegiatan dalam hal pelayanan untuk memenuhi harapan bagi pengguna jasa, agar pelayanan jasa dapat memuaskan pengguna jasa. Menurut Tjiptono (2001:160) mengemukakan bahwa gejala buruknya kualitas pelayanan
p-ISSN 2302-0970

e-ISSN 2723-0201

akan terjadi apabila tuntutan serta permintaan pelanggan tidak dipenuhi, bahkan tidak tertanganinya permasalahan tersebut secara tepat dan cepat, dapat menyebabkan pelanggan berprasangka buruk dan sakit hati.

Kualitas adalah suatu hal tentang proses produksi barang, maupun bidang jasa, contohnya jasa suatu layanan. Kualitas merupakan syarat utama diterimanya suatu produk di pasar. Suatu produk dikatakan berkualitas apabila produk tersebut mampu memenuhi harapan pelanggan. Meningkatnya kualitas pelayanan dan kuantitas suatu produk untuk memuaskan pelanggan, merupakan salah satu hal yang menjadi suatu tujuan bagi setiap instansi, terutama instansi swasta (perusahaan). Fandy Tjiptono (1997) dalam Kamaruddin Sellang, 2016: 146) bahwa kata 'kualitas' mengandung banyak dfenisi dan makna. Beberapa contoh defenisi yang kerapkali dijumpai antara lain;

1. Kesesuaian dengan persyaratan/tuntutan;

2. Kecocokan untuk pemakaian;

3. Perbaikan/penyempurnaan berkelanjutan;

4. Bebas dari kerusakan/cacat;

5. Pemenuhan kebutuhan pelanggan semenjak awal dan setiap saat;

6. Melakukan segala sesuatu secara benar semenjak awal;

7. Sesuatu yang bisa membahagiakan pelanggan

Wojowarsito (Sellang, 2016) bahwa quality adalah kualitas, mutu, kecakapan, sifat, macam, jenis". Ndraha (Mustafa, 2012) mengemukakan bahwa quality adalah "characteristic, properti or attitude, character or nature", setiap orang, barang atau zat memiliki kualitas, dan kualitas ini membedakan antara orang, barang atau zat yang satu dengan lainnya. Hasbar (Sellang, 2016) bahwa pelayanan diberikan kepada masyarakat itu menuntut kualitas. Pelayanan bdiselenggarakan oleh pemerintah melalui aparatnya, meskipun tidak bertujuan untuk mencari keuntungan, tetapi harus mengutamakan kualitas pelayanan yang sesuai ndengan tuntutan, harapan serta sesuai dengan kebutuhan masyarakat yang akan dilayani. Para aparatur (pegawai) haruslah menyadari posisi dan peran mereka sebagai pelayan publik. Bila dimata masyarakat kesan muncul tidak demikian, berarti tugas pelayanan yang diterima selama ini bukanlah produk pelayanan sepenuh hati, 
melainkan pelayanan yang hanya didasari kewajiban sebagai abdi negara.

Undang-undang No. 5 tahun 2009 tentang pelayanan publik memberikan defenisi pelayanan publik merupakan semua kegiatan atau segala rangkaian kegiatan dalam pemenuhan kebutuhan pelayanan yang sesuai dengan perundang-undangan bagi setiap warga negara dan penduduk atas barang, jasa, dan/atau pelayanan administratif yang disediakan oleh penyelenggara pelayanan publik. Mahmudi (Sellang, 2016)pelayanan publik merupakan kegiatan pelayanan yang dilaksanakan oleh penyelenggaraan pelayanan publik dalam bentuk upaya unutk pemenuhan kebutuhan publik serta pelaksanaan ketentuan perundang-undangan. Penyelenggara pelayanan publik adalah instansi pemerintah yang meliputi, Satuan kerja/satuan organisasi kementerian, Departemen, Lembaga pemerintah non departemen, Kesekteriatan lembaga tertinggi dan tinggi negara, misalnya, Badan usaha milik negara (BUMN), Badan hukum milik negara (BHMN), Badan usaha milik daerah (BUMD), Instansi pemerintah lainnya, baik pusat maupun daerah termasuk dinas-dinas dan badan.

Pemberian pelayanan publik, instansi penyedia pelayanan publik harus memperhatikan asas pelayanan publik Mahmudi (Sellang, 2016) yaitu :

1. Transparansi, yaitu pemberian pelayanan publik harus bersifat terbuka, mudah dan dapat diakses oleh semua pihak yang membutuhkan dan desediakan secara memadai serta mudah dimengerti.

2. Akuntabilitas, yaitu pelayanan publik harus dapat dipertanggung jawabkan sesuai dengan ketentuan peraturan perundangundangan.

3. Kondisional, yaitu pemberian pelayanan publik harus sesuai dengan kondisi dan kemampuan pemberi dan penerima pelayanan dengan tetap berpegang pada prinsip efisiensi dan efektivitas.

4. Partisipatif, yaitu mendorong peran serta masyarakat dalam penyelengaraan pelayanan publik dengan memeprhatikan aspirasi, kebutuhan dan harapan masyarakat.

5. Tidak diskriminatif (kesamaan hak) yaitu pemberian pelayanan publik tidak boleh bersifat diskriminatif, dalam arti tidak membedakan suku, ras agama, golongan, gender, status sosial dan ekonomi.
6. Keseimbangan hak dan kewajiban, yaitu pemberi dan penerima pelayanan publik harus memenuhi hak dan kewajiban masing-masing pihak.

Zeithaml, Parasuraman, Berry (Ahmad, 2018) Menawarkan indikator untuk mengetahui kualitas pelayanan yang dirasakan secara nyata oleh konsumen, ada indikator ukuran kepuasan konsumen yang terletak pada lima dimensi kualitas pelayanan

1. Tangibles ketampakan fisik, yaitu kualitas pelayanan yang berupa sarana fisik perkantoran, komputerisasi administrasi, runag tunggu, tempat informasi.

2. Realibility keandalan, yaitu kemampuan dan keandalan untuk menyediakan pelayanan yang terpercaya.

3. Responsiviness daya tanggap, yaitu kesanggupan untuk membantu dan menyediakan pelayanan secara cepat dan tepat, serta tanggap terhadap keinginan konsumen.

4. Assurance jaminan, yaitu kemampuan dan keramahan serta sopan santun pegawai dalam meyakinkan kepercayaan konsumen.

5. Emphaty empati, yaitu sikap tegas tetapi penuh perhatian dari pegawai terhadap konsumen.

Kepuasan pelanggan merupakan kualitas pelayanan yang dipandang dari kepentingan konsumen dalam hal ini adalah pasien. Endang (Mamik, 2010) Kepuasan pasien merupakan evaluasi atau penilaian setelah memakai suatu pelayanan, bahwa pelayanan yang dipilih setidak-tidaknya memenuhi atau melebihi harapan. Sedangkan menurut (Pohan, 2007). Menyebutkan bahwa kepuasan pasien adalah tingkat perasaan pasien yang timbul sebagai akibat dari kinerja layanan kesehatan yang diperolehnya, setelah pasien membandingkan dengan apa yang diharapkannya. Menurut Peraturan Menkes RI No.269/Menkes/Per/III/2008 tentang rekam medis bab 1 pasal 1 . Pasien adalah setiap orang yang melakukan konsultasi masalah kesehatan untuk memperoleh pelayanan kesehatan yanmg diperlukan baik secara langsung maupun tidak langsung kepada dokter atau dokter gigi. Undangundang Nomor 44 Tahun 2009 tentang hak dan kewajiban pasien :

1. Memperoleh informasi mengenai tata tertib dan peraturan yang berlaku di rumah sakit. 
2. Memperoleh layanan yang manusiawi, adil, jujur, dan tanpa diskriminasi.

3. Memperoleh tentang hak dan kewajiban pasien.

4. Memperoleh layanan kesehatan yang bermutu sesuai dengan standar profesi dan standar prosedur operasional.

5. Memperoleh pelayanan yang efektif dan efisien sehingga pasien terhindar dari kerugian fisik dan materi.

6. Mengajukan pengaduan atas kualitas pelayanan yang didapatkan.

7. Memilih dokter dan kelas perawatan sesuai dengan keinginan dan peraturan yang berlaku di rumah sakit.

8. Meminta konsultasi tentang penyakit yang di deritanya kepada dokter lain yang mempunyai Surat Izin Praktik (SIP) baik dalam maupun luar Rumah Sakit.

9. Mendapat privasi dan kerahasiaan penyakit yang di derita termasuk data-data medisnya.

Sementara itu ahli lain Moison dkk (Dwilaksono, 2006) mengemukakan indikator kepuasan pasien yaitu:

1. Pelayanan keperawatan, Pelayanan keperawatan bertujuan untuk memenuhi kebutuhan dasar manusia yang diberikan dalam bentuk asuhan keperawatan komprehensif yakni secara menyeluruh bio-psiko-sosio-spiritual. Dilakukan melalui proses pengkajian terhadap penyebab utama tidak terpenuhinya kebutuhan dasar manusia.

2. Harga. Harga merupakan hal yang terpenting untuk penentuan kualitas agar mencapai kepuasan pelanggan.

3. Lokasi rumah sakit/puskesmas. Hal ini meliputi letak rumah sakit, Posisi kamar dan lingkungannya. Merupakan salah satu aspek yang menentukan pertimbangan dalam memilih rumah sakit.

4. Fasilitas. Fasilitas rumah sakit akan menentukan penilaian kepuasan pasien, seperti fasilitas kesehatan baik sarana dan prasarana, parkiran, serta ruang tunggu yang nyaman dan ruang kamar rawat inap. Walaupun hal ini tidak terlalu vital dalam menentukan penilaian kepuasan pasien, tetapi rumah sakit perlu memberikan perhatian pada fasilitas rumah sakit dalam menyusun strategi supaya dapat menarik pasien.

5. Image. citra, reputasi dan kepedulian rumah sakit terhadap lingkungan. Image juga dapat memegang peranan penting terhadap kepuasan pasien dimana pasien memandang rumah sakit mana yang akan dibutuhkan dalam proses penyembuhan.

6. Suasana. Hal ini meliputi keamanan, keakraban dan tata lampu. Suasana rumah sakit yang tenang, nyaman, sejuk, dan indah sangat mempengaruhi atas kepuasan pasien dalam proses penyembuhannya.

7. Komunikasi. Informasi yang diberikan kepada pihak penyedia jasa dan keluhan dari pasien. Bagaimana keluhan dari pasien dengan cepat diterima oleh penyedia jasa terutama perawat dalam memberikan bantuan terhadap keluhan pasien.

\section{B. METODE PENELITIAN}

Tipe penelitian yang digunakan adalah deskriptif kuantitatif. Dasar penelitian yang digunakan adalah survey, yaitu pembagian kuesioner kepada responden yang berisi pertanyaan-pertanyaan mengenai hal yang berhubungan dengan penelitian. Populasi penelitian ini adalah keseluruhan pasien atau masyarakat yang berada pada wilayah kerja Puskesmas Kecamatan Panca Rijang Kabupaten Sidenreng Rappang, Berdasarkan hasil observasi jumlah pasien pada awal bulan januari tahun 2019 kunjungan rawat jalan sebanyak 1.786 orang dan jumlah rujukan rawat jalan sebanyak 328 orang lalu ditambah jadi totalnya 2114 orang, Sampel yang dipilih adalah Insidental Sampling (kebetulan) yaitu siapa saja yang secara tidak sengaja bertemu dengan peneliti maka orang tersebut dapat dijadikan sampel dari populasi keseluruhan jumlah pasien rujukan rawat jalan sebanyak 48 orang dan kunjungan rawat jalan sebanyak 47 orang pada tanggal 15 mei 2019 di Puskesmas. Dalam pengambilan sampel diambil sebanyak $10 \%$ menggunakan rumus Slovin sebanyak 95 orang yang dijadikan sebagai responden. Adapun teknik pengumpulan data yang digunakan yaitu observasi, wawancara studi kepustakaan, dan kuesioner. Teknik Analisis data yang digunakan adalah analisis tabulasi frekuensi.

\section{HASIL DAN PEMBAHASAN}

Hasil pengolahan data diatas menunjukkan bahwa dari 95 jumlah responden Puskesmas Kecamatan Panca Rijang mengenai kelengkapan fasilitas ruang tunggu sudah memadai dikategorikan Kurang 
Baik dengan jumlah rata-rata $57 \%$. Berdasarkan analisis data dan wawancara penulis menyimpulkan bahwa kualitas pelayanan berupa sarana fisik ruang tunggu kurang memadai alangka baiknya pihak puskesmas lebih memfasilitasi lagi ruang tunggu agar dapat memenuhi kualitas pelayanan yang baik.

Puskesmas Kecamatan Panca Rijang mengenai kemampuan petugas dalam memberikan pelayanan secara profesional pada saat jam sibuk dikategorikan Kurang Baik dengan jumlah rata-rata $57,2 \%$. Berdasarkan analisis data dan wawancara penulis menyimpulkan bahwa kemampuan petugas dalam memberikan pelayanan secara profesional masih kurang profesionel karena masih terjebak dengan pekerjaan sehingga kewelahan menyelesaikan tugasnya. Ketanggapan petugas dapat menyesuaikan pelayanan dengan cepat terhadap pasien dikategorikan Kurang Baik dengan jumlah rata-rata $57 \%$. Berdasarkan analisis data dan wawancara penulis menyimpulkan bahwa ketanggapan petugas dalam menyesuaikan pelayanan dengan cepat terhadap keluhan pasien masih kurang karena kemampuan untuk hal tersebut belum memadai dan juga terkendala pada tenaga medis.

Keramahan petugas terhadap pasien dikategorikan Kurang Baik dengan jumlah rata-rata $60 \%$. Berdasarkan analisis data dan wawancara penulis menyimpulkan bahwa petugas masih ada yang kurang ramah sehingga hal tersebut dapat menimbulkan kesan negatif bagi yang mendapatkan pelayanan. Sikap Adil petugas terhadap semua pasien dikategorikan Kurang Baik dengan jumlah rata-rata $60,2 \%$. Berdasarkan analisis data dan wawancara penulis menyimpulkan bahwa seharusnya petugas tidak membeda-bedakan pasien karena sebagai pemberi layanan harus bersikap adil kepada yang dilayani.

Akumulasikan hasil rata-rata persentase dari 5 item pertanyaan pada Indikator Kualitas Pelayanan di atas, maka didapatkan hasil rata-rata persentase, yaitu $58,2 \%$ jadi dapat ditarik suatu kesimpulan bahwa pada indikator ini berada pada kategori Kurang Baik. Hal penting dalam memberikan pelayanan adalah bagaimana seorang petugas bersungguh-sungguh dalam menghadapi pasien. Mereka harus paham akan tugas dan fungsi mereka sebagaimana yang seharusnya. Selain itu petugas juga perlu memperhatikan mengenai hal-hal seperti keramahan sikap adil, sikap profesional, dan tanggap dalam memberikan pelayanan sehingga bisa memberikan kesan yang baik akan pelayanan yang diterima oleh pasien".

Pelayanan keperawatan sudah memenuhi kebutuhan dasar pasien secara menyeluruh dikategorikan Baik dengan jumlah rata-rata $70,2 \%$. Berdasarkan analisis data dan wawancara penulis menyimpulkan bahwa pelayanan keperawatan dalam memenuhi kebutuhan dasar pasien yang diberikan dalam bentuk asuhan secara menyeluruh sudah baik. Biaya pengobatan sesuai dengan kualitas pelayanan yang diberikan oleh petugas di dikategorikan Baik dengan jumlah rata-rata $64 \%$. Berdasarkan analisis data dan wawancara penulis menyimpulkan bahwa biaya pengobatan sudah sesuai dengan pelayanan yang didapatkan. Tempat atau lokasi puskesmas yang letaknya mudah dijangkau dikategorikan Kurang Baik dengan jumlah rata-rata $60,4 \%$. Berdasarkan analisis data dan wawancara penulis menyimpulkan bahwa tempat atau lokasi puskesmas lataknya mudah dijangkau kata bapak Ibrahim. namun penulis menyimpulkan bahwa lokasi dan tempat masih kurang baik karena melihat hasil rekapitulasi 54 responden menjawab kurang baik itu artinya lokasi puskesmas masih belum sesuai pada kenginan pasien.

Kelengakapan fasilitas seperti tempat parkir apakah sudah memadai dikategorikan Kurang Baik dengan jumlah rata-rata 56,6\% $=57 \%$. Berdasarkan analisis data dan wawancara penulis menyimpulkan bahwa kelengkapan fasilitas tempat parkir kurang memadai walaupun hal ini tidak terlalu vital namun pihak puskesmas perlu memeberikan perhatian agar dapat menyusun starategi untuk menarik pengunjung. Dekorasi ruangan dikategorikan Kurang Baik dengan jumlah rata-rata $60 \%$. Berdasarkan analisis data dan wawancara penulis berkesimpulan bahwa penilaian tergantung dari individu itu sendiri karena pada penilaian skor dari hasil analisis diatas menunjukkan ada 66 responden yang menjawab kurang baik dan berdasarkan hasil wawancara salah satu responden mengatakan baik.

suasana kenyamanan puskesmas dikategorikan Baik dengan jumlah rata-rata $64,2 \%$. Berdasarkan analisis data wawancara 
suasana keamanan puskesmas sudah baik dan bagi pihak puskesmas alangkah baiknya tetap mempertahankan kualitas susana puskesmas sehingga yang berkunjung ke puskesmas akan sangat senang dan memberikan pendapat positif sehingga akan terkesan baik.

Hasil pengolahan data menunjukkan bahwa dari 95 jumlah responden. Puskesmas Kecamatan Panca Rijang mengenai cara petugas dalam memberikan informasi terhadap pasien dikategorikan Baik dengan jumlah rata-rata $69 \%$. Berdasarkan analisis data dan wawancara penulis berkesimpulan bahwa cara petugas memberi informasi sudah baik karena melihat hasil analisi data ada 45 responden yang menjawab baik dan juga responden yang diwawancara juga mengatakan baik dan pihak puskesmas haruslah mempertahankan hal itu di wilayah kerjanya.

Akumulasikan hasil rata-rata persentase dari 7 item pertanyaan pada Indikator Kepuasan Pasien di atas, maka didapatkan hasil rata-rata persentase, yaitu $64 \%$ berada pada kategori Baik. "Jadi dapat ditarik suatu kesimpulan bahwa pada indikator ini pihak puskesmas kecamatan panca rijang dalam memenuhi harapan pasien sudah baik dan mampu menjaga keamanan dan tata cara memberi informasi mudah dipahami sehingga akan memberi kesan baik". Adapun total keseluruhan nilai dari Variabel X (Kualitas Pelayanan) adalah sebesar 1396. Untuk mengetahui jumlah persentasenya, maka dapat dihitung dengan menggunakan rumus sebagai berikut:

$$
=\frac{1396}{5 \times 5 \times 95} \times 100 \%=\frac{1396}{2375}=0,58 \times 100 \%=58 \%
$$

Jadi, nilai dari indikator Kualitas Pelayanan sebesar $58 \%$ dari $100 \%$ hasil yang diharapkan. Adapun total keseluruhan nilai dari Variabel $Y$ (Kepuasan Pasien) adalah sebesar 2149. Untuk mengetahui jumlah persentasenya, maka dapat dihitung dengan menggunakan rumus sebagai berikut:

$$
=\frac{2149}{5 \times 7 \times 95} \times 100 \%=\frac{2149}{3325}=0,64 \times 100 \%=64 \%
$$

Jadi, nilai Kepuasan Pasien sebesar $64 \%$ dari $100 \%$ hasil yang diharapkan. Adapun untuk mengetahui nilai dari variabel $X$ dan variabel $Y$ yaitu sebagai berikut:

$$
=\frac{3545}{5 \times 12 \times 95} \times 100 \%=\frac{3545}{5700}=0,62 \times 100 \%=62 \%
$$

Jadi, nilai untuk mengetahui pengaruh Kualitas Pelayanan Terhadap Kepuasan Pasien di Puskesmas Kecamatan Panca Rijang Kabupaten Sidenreng Rappang, sebesar $62 \%$ dari $100 \%$ hasil yang diharapkan, dimana ini tergolong dalam kategori baik.

1. Model Regresi dan Pengujian Hipotesis menggunakan SPSS 16.0.

Hasil dari tabel Model Summary, Pada bagian ini ditampilkan nilai $R=0,178$ dan koefisien Determinasi $R_{\text {square atau }}\left(R^{2}\right)$ sebesar 0,032 (adalah pengkuadratan dari koefisien korelasi, atau $0,178 \times 0,178=0,032$ x $100 \%=32 \%)$, sedangkan sisanya $(100 \%$ $32 \%=68 \%$ ) Hal ini menunjukkan untuk mencari besar pengaruh Kualitas Pelayanan $(X)$ terhadap Kepuasan Pasien $(Y)$ dengan ini nilai yang dicari yaitu sebesar $68 \%$.

Hasil dari uji ANOVA pada bagian ini ditampilkan hasil yang diperoleh adalah nilai $\mathrm{F}=3.027$ dengan tingkat probabilitas sig. 0,085 . oleh karena probabilitas $(0,085)$ jauh lebih besar dari 0,05 maka model regresi tidak bisa dipakai untuk memprediksi kepuasan pasien. Untuk menguji kebenaran hipotesis dalam penelitian ini, dilakukan uji $F$. Untuk mengetahui bahwa ada pengaruh/Signifikan dapat diketahui dengan melihat dari level of significant $\alpha=0,05$. Jika nilai signifikansi lebih kecil dari 0,05 maka Ho ditolak dan $\mathrm{Ha}$ diterima. Berdasarkan hasil olah data pada tabel ANOVA, maka diketahui nilai $F_{\text {hitung }}$ yang diperoleh sebesar 3.027 dengan tingkat signifikan $0,085(F>0.05)$ yang berarti bahwa variabel Kualitas Pelayanan $(X)$ tidak mempunyai pengaruh/signifikan terhadap kepuasan pasien ( $\mathrm{Y}$ ). Dari hasil tersebut berarti bahwa model regresi tidak dapat digunakan untuk memprediksi kepuasan pasien. Hasil dari uji ANOVA pada bagian ini ditampilkan hasil yang diperoleh adalah nilai $F=3.027$ dengan tingkat probabilitas sig. 0,085 . oleh karena probabilitas $(0,085)$ jauh lebih besar dari 0,05 maka model regresi tidak bisa dipakai untuk memprediksi kepuasan pasien. Untuk menguji kebenaran hipotesis dalam penelitian ini, dilakukan uji $F$. Untuk mengetahui bahwa ada pengaruh/Signifikan dapat diketahui dengan melihat dari level of significant $\alpha=$ 0,05 . Jika nilai signifikansi lebih kecil dari 0,05 maka Ho ditolak dan $\mathrm{Ha}$ diterima. Berdasarkan hasil olah data pada tabel ANOVA, maka diketahui nilai $F_{\text {hitung yang }}$ diperoleh sebesar 3.027 dengan tingkat 
signifikan $0,085(F>0.05)$ yang berarti bahwa variabel Kualitas Pelayanan (X) tidak mempunyai pengaruh/signifikan terhadap kepuasan pasien ( $\mathrm{Y}$ ). Dari hasil tersebut berarti bahwa model regresi tidak dapat digunakan untuk memprediksi kepuasan pasien.

Berdasarkan hasil dari uji coefficients, pada bagian ini dikemukakan nilai konstanta (a) $=19.827$ dan beta $=0,190$ serta harga $t-$ hitung dan tingkat signifikansi $=0,000$. Maka model regresi yang digunakan dalam penelitian ini untuk mengukur pengaruh Kualitas Pelayanan terhadap Kepuasan Pasien di Puskesmas Kecamatan Panca Rijang, dapat dianalisa berdasarkan koefesien-koefesiennya sebagai berikut: $Y=$ $19.827+0,190 \mathrm{X}$, dari fungsi regresi di atas, maka dapat dijelaskan:

1. Jika variabel Kualitas Pelayanan (X) berubah, maka Kepuasan Pasien $(Y)$ juga akan berubah. Tanda positif menunjukkan perubahan yang searah. Apabila Kualitas Pelayanan. meningkat, maka Kualitas Pelayanan juga akan meningkat dengan koefisien regresi sebesar 0,190 Dan sebaliknya, jika Kepuasan Pasien menurun, maka Kualitas Pelayanan juga akan menurun dengan koefisien regresi sebesar 0,190.

2. Nilai konstanta sebesar 19.827 menunjukkan bahwa, jika semua variabel konstan maka Kualitas Pelayanan masih bersifat positif.

3. Berdasarkan nilai beta 0,190 , diketahui bahwa variabel yang berpengaruh dominan terhadap Kualitas Pelayanan (X) adalah Kepuasan Pasien $(Y)$, berdasarkan nilai beta yang besar.

Uji statistik $t$ untuk menunjukkan seberapa jauh pengaruh satu variabel penjelas/independen secara individual menerangkan variasi variabel dependen berdasarkan tabel coefficients hasil olah data SPSS, maka diketahui bahwa:

a. Nilai $t_{\text {hitung }}$ variabel Kualitas Pelayanan (X) 1.740 dengan tingkat signifikansi 0.000 .

b. Hipotesis berdasarkan uji t dirumuskan secara statistik berikut.

$\mathrm{Ha}: \mathrm{P}_{\mathrm{yx}} \neq 0$

Ho : $P_{y x} \neq 0$

Keputusan : Ternyata nilai $t_{\text {hitung }} \geq \mathrm{t}$ tabel $1.740 \geq 1.661$ maka Ho ditolak dan $\mathrm{Ha}$ diterima, artinya signifikan. Jadi kualitas pelayanan kesehatan berpengaruh/signifikan
p-ISSN 2302-0970

e-ISSN 2723-0201

terhadap kepuasan pasien Puskesmas Kecamatan Panca Rijang Kabupaten Sidenreng Rappang.

\section{KESIMPULAN}

Berdasarkan hasil penelitian yang telah diuraikan maka dapat disimpulkan bahwa:

1. Kualitas pelayanan kesehatan puskesmas Kecamatan Panca Rijang memiliki nilai sebesar $58 \%$ dari $100 \%$ hasil yang diharapkan dengan kategori kurang baik.

2. Kepuasan pasien puskesmas Kecamatan Panca Rijang memiliki nilai sebesar $64 \%$ dari $100 \%$ hasil yang diharapkan dengan kategori baik.

3. Nilai $t_{\text {hitung }} \geq t_{\text {tabel }} 1.740 \geq 1.661$ maka Ho ditolak dan Ha diterima, artinya signifikan. Jadi kualitas pelayanan kesehatan berpengaruh/signifikan terhadap kepuasan pasien Puskesmas Kecamatan Panca Rijang Kabupaten Sidenreng Rappang.

\section{E. REFERENSI}

Ahmad, B. (2018). Pelayanan Publik Teori dan Praktik. Bandung: Manggu Makmur Tanjung Lestari.

Akbar, S. (2017). Evektivitas Program Badan Pelayanan Jaminan Sosial Terhadap Pelayanan Kesehatan Keluarga Miskin Di Rumah Sakit Nene Mallomo Kabupaten Sidenreng Rappang. Sidenreng Rappang: STISIP Muhammadiyah Rappang Sidrap.

Dwilaksono, A. (2006). Analisis Pengaruh Fasilitas, Kualitas Pelayanan dan Kepuasan Pelanggan terhadap Minat Mareferensikan. Jurnal Buletin Penelitian Sistem Kesehatan., Vol. 9. No. 4.

Mamik. (2010). Organisasi dan Manajemen Pelayanan Kesehatan dan Kebidanan . Surabaya: Prins Media.

Pohan, I. (2007). Jaminan Mutu Layanan Kesehatan. Jakarta: Penerbit Buku Kedokteran ECG.

Sabarguna. (2009). Manajemen Rumah Sakit. Jakarta: Sagung Seto. 
Sellang, K. (2016). Administrasi dan Pelayanan Publik Antara Teori dan Aplikasi. Yogyakarta: Penerbit Ombak. 